\title{
Realization of Pragmatic Function of Informing of Reporting Category (as Exemplified in English and Russian)
}

\author{
Gulnara Lutfullina, ${ }^{1, *}$, and Veronika Sabitova ${ }^{2}$ \\ ${ }^{1}$ Kazan State Power Engineering University, Department of Foreign Languages, 420066 Krasnoselskaya St., 51, Kazan, Russia \\ ${ }^{2}$ Kazan Federal University, Institute of International Relations, History and Oriental Studies, 420008, Pushkina St., 1/55, Kazan, \\ Russia
}

\begin{abstract}
This article considers the pragmatic potential of the reporting category as a core component of the indirect evidentiality field. The purpose of the article is to determine methods of realization of the pragmatic function of reporting category informing. The article analyses examples taken from mass-media programs about information technologies news and determines 2 analysing strategies for pragmatic potential. The example analysis demonstrated that common pragmatic function of informing is a priori specific for mass-media news programs; in this case, examples of informing about latest news and updates in science and technology. The essence of informing process suggests retelling of another's information or the realization of the reporting category. In English, anonymous sources are represented less within the informing process and the category of inference is used. In the Russian language, information is often given as the fruits of labour, the achievement, the activity result of particular subjects who are suggested to be sources of information.
\end{abstract}

\section{Introduction}

Pragmatic potential of evidentiality is underexplored in works of scientists from Russia and abroad. This category means explicit or implicit indication of a source of information. 'Direct' evidentiality suggests receiving the information as a result of direct and personal access to it, i.e. the perception itself. Indirect evidentiality means receiving the information from the third parties or as a result of conclusion on the basis of facts $[1$, p. 134; 2 , p. 216]. It is possible to detect a number of variants of pragmatic potential analysis. The relevance of this study is to make comparative analyses of means to realize the informing pragmatic function by the reporting category in Russian and English. The subject of this analysis is to explore means identified to realize the informing pragmatic function by reporting category. The object of the study is to discover peculiarities of both languages. The purpose of this article is to consider the most frequent means identified to realize the informing pragmatic function by reporting category in Russian and English. The research method of total sampling was used. Two methods of analysing pragmatic potential are also considered.

\section{Results}

In this article, the analysis of 2 information programs which are dedicated to the latest news in technology and informatics is given. The choice can be attributed to the fact that these programs are implementing the evidential function of transferring the information from the third parties itself and more specifically - from developers and producers of new technical products. The interest is methods of transferring information from third parties. The object of analysis is 2 programs: 1 ) «Чудо техники: Что нужно знать о крови, плюсы японской мочалки и вантуза с гидроударом» (18.02.2018), channel NTV, 34 минуты / 'Technological Wonder: What You Need to Know about Blood, Pluses of Japanese Bath Wisp and Force Cup with Hydroshock', 34 minutes [3]; 2) Tech News Today 1862: Screen Infiltration (27.09.2017), 44 minutes [4]. Programs were selected taking into account their theme and duration. IT theme is chosen as requiring the littlest personal access of journalists to the information, i.e. only pragmatic function of informing of the reporting category was understood as a core component of the indirect evidentiality field. [5, p. 3].

In the 1st program with the continuous sampling method, there were 20 examples found which can be divided into the following groups. Within the video it is not necessary to indicate the source of information - you can watch an extract from interview, e.g.: 1) doctors' opinion (with indications of names) on the character dependence on blood type; 2) opinion on the convenience of egg peeling device made by restaurants' technologists, actors, an expert and show master of the program, Yuriy (18:46).

(1) Наш обозреватель В. Боровой проверил устройство / Our observer V. Borovoy tested the device

Corresponding author: gflutfullina@mail.ru 
4:24; (2) Компания из Швейцарии представила устройство для защиты дома / Далее описание устройства / Switz company presented a houseprotecting device / Followed by description of the device 4:28; (3) Создатели назвали устройство Келвин / Creators named the device Calvin 5:14; (4) B Kopee есть мультики с группой крови / There are cartoons with a blood type in Korea 9:23; (5) Современные доктора стараются не злоупотреблять универсальной кровью / а переливать каждому свою; / Modern doctors aim not to abuse the universal blood / but to transfuse to each his own (6) В наши дни правительство борется с фирмами, требующими группу крови / Nowadays the government fights firms requiring the blood type 14:23; (7) Власти страны разрешили тестировать эти цифровые технологии / The state authorities allowed testing these digital technologies 16:01. (8) В 2014 в Лондонской канализации обнаружили ужасный зазор / In 2014 а horrible backlash was found in the London drainage, 20:56; (9) В Азии доминирует 3 группа крови / The В blood type is dominating in Asia, 12:25; (10) В Японии увлечение пошло на спад / In Japan a fancy became to diminish, 13:23; (11) На дорогах Финляндии скоро появятся водители без прав / On Finland roads drivers without driving license will appear, 15:55;

A big unit of facts is reported without the source of information indication. However, in the reported information particular producers and inventors are mentioned, thus we can suggest that they exactly were the source of information for mass media (examples from 1 to 7). In this case, it is possible to refer to the implicated category of indirect evidentiality. The presence of a source of information can be implied with indication of a particular localization of a reported fact. In this case the source of information can be presented by representatives of regions, which is under consideration (examples from 8 to 11). The role of mass media consists precisely in the informing on facts, which are rarely witnessed by journalists themselves. The choice of programs about technical news and scientific discoveries suppose the interest in informing and projection this information.

(1) Оказалось, что на поверхности клетки крови взаимодействуют между собой / It turned out that on a cell surface blood cells are interacting with each other 10:13; (2) Выяснилось, что носители 4 группы можно переливать любую группу крови / It emerged that the $4^{\text {th }}$ blood type bearers can be transfused with blood of any type 7:58; (3) В Японии появились исследования о том, что есть связь группы крови с привычками. В этой стране указывают какой группы работники / In Japan research was made about the link between blood type and habits. In this country blood type of a worker is indicated 10:13; (4) Известно, что наследственная болезнь крови / It is known that heritable blood disease 11:45; (5) Оказывается, улучшается зрение после упражнений / It turned out that the sign gets better after exercise 32:00; (6) Наука уже дано выяснила / что генетические варианты существуют не только у агглютиногена крови. / Science emerged a long time ago that genetic variants are possible not only for the blood agglutinogen 9:42; (7) Наука такое не одобряет / Science does not approve that 14:29; (8) Из инструкции ясно / что не все так просто / It is clear from the instruction that it's not all that simple 20:34;

The next unit of examples is represented by anonymous sources of information (examples from 1 to 5) and is expressed with impersonal parenthesis. A special interest is given to utterances with generalized anonymous source referred as science (examples 6 and 7) or indication of a written document as a source of information (example 8).

(1) Долгое нахождение в темной комнате может привести к ослаблению работы мозга / $K$ такому выводу пришли ученые Мичиганского университета / Ухудшение активности на $30 \%$ / A long stay in the dark room can cause the weakening of brain work / This conclusion was made by the Michigan University scientists / Decreasing of the effectivity on 30\% 4:20; (2) Ученье проверили диету и пришли к выводу / что диета не эффективна / Scientists revised a diet and came to conclusion / that the diet is not effective 9:27; (3) Практический вывод авторов исследования / что полезная еда для детей / Practical conclusion of the research authors is / that wholesome food for children 15:10; (4) Ученые Бонского университета Германии установили / что жирная еда обостряет воспалении Scientists of the Bonn University in Germany determined that oily food can aggravate inflammation 15:01; (5) Ученые из Университета Техаса пришли к выводу / что регулярные физические нагрузки могут омолодить сердце тело / Scientists from the Texas university came to the conclusion that regular exercises can bring young blood to heart and body 31:21.

In the above-mentioned examples, the information is presented as a fruit of labor, an achievement, a result of action of a number of people who, as it is supposed by sources of information, came to conclusion, determined, gave a practical conclusion of research authors (examples from 1 to 5).

(1) Татьяна Андреева похудела на диете по группе крови / Все члены семьи интервьюируются / По мнению Татьяны / это питание мне помогает поддерживать вес / Tatyana Andreeva lost her weight on a blood-type diet / All family members are interviewed / According to Tatyana, / this food helps me to keep weight 9:29; (2) Натуропат Питер Диадамо / который 20 лет назад придумал диету по группе крови / Согласно его теории / первая группа «Охотники» должны есть только сырые овощи / Naturopath Peter Diadamo / who created the blood-type diet 20 years ago / According to his theory, / $1^{\text {st }}$ type, 'hunters', should eat only raw vegetables 11:02; (3) Пo современным данным / существуют более 30 групп крови / According to the latest data, / there are more than 30 blood types existing 11:23; (4) Статистика Гарварда говорит / что статистика болезней не зависит от группы крови / Harvard statistics says that / the illness statistics does not depend on a blood type ; (5) Вал писем поступает с просьбой проверить разные интересные устройства / $A$ dime a dozen of letters is coming these days 16:11; (6) Если верить рекламе / чистка яиц этим устройством экономит время - 
революционная машина / If advertisement is something to go by, / it seems that the egg peeling with this device saves your time - a revolutionary machine $20: 12$; (7) Производитель уверяет, попробовав однажды / вы никогда не откажетесь / The producer assures that once / have tried you will never refuse 21:39; (8) Вячеслав отвечает / что стоит специальное ограничение / чтобы кровать сама не поднималась. Говорит / что это не работа / а образ жизни / Vyacheslav answers / that there is a special limitation / for bed not to lift independently. He says / that it is not a work / but the way of life 31:06; (9) Ученые из Университета Техаса отметили / что эластичность главной камеры сердца улучшилась на $25 \%$ / Scientists from the Texas University noticed / that the compliance of the main heart chamber improved on 25\% 29:17; (10) Однако можно получить другой эффект / даже если вы занимаетесь регулярными нагрузками / Его зафиксировали Ученые из университета Западного Онтарио / However, you can get another effect / even if you do regular exercise / It was noticed by the Western Ontario University scientists 30:12.

The last unit of examples represents the realization of the core category of the indirect evidentiality field reporting category. Sources of information are determined and clearly expressed.

The second program is dedicated to the discussion of Amazon devices' technical abilities. This show is organized as a dialogue of two people. With continuous sampling method there were 60 examples found. In this program next examples were detected:

(1) You get this little device and you say / 'Discover all the vices', and if you have any smart devices in your home it will find them 22.54; (2) I asked my aunt / if she has any echoes in her house and she said / 'No, because they might be listening to me' 23.40; (3) If I have Stacy / she would say / 'Yes, IOT is insecure, be worry about that' 26.47; (4) If you ask the echo show to play Youtube video currently, it will tell you that Google doesn't support Youtube on that device anymore 2.14.

Direct speech is used in the representation of information but it can not be referred as the indirect evidentiality category (examples from 1 to 3 ). However, there is an interesting example in which direct speech is addressed to the source of information (example 4).

(2) The Amazon echo show often seems destined to end up in the kitchen / with its screen that would make watching instructional recipe videos / a piece of cake / get it 2.05 ; (2) There's a chance that one in 1 million people are you doppelganger 7.40; (3) The probability of false match is different for twins 7.56; (4) Face ID data including your mathematical representations of your face are as secure as Apple could make them. 6.46; (5) Signal might be known as one of the most secure messaging apps available 11.55; (6) That's where you start to get in trouble with Facebook 13.54; (7) That's the way how signal works 14.09; (8) On Apple TV I can just say what I want 32.35; (9) Echo Connect will let you make and accept landline phone calls from your Echo devices 33.54; (10) It plugs into a standard form jack and also into your Echo 33.58
Separately the unit of facts without source of information is presented. But we cannot say about the implication of a source of information with indication of subject of fact. In this case the description of programs and devices' abilities supposes the presence of these companies who produced this and explained these functions (examples from 1 to 10 ).

(1) I read this this morning 2.52; (2) This is what Youtube really wants 4.02; (1) It is kind of 'they saidthey said' sort of thing 2.45 .

The interest lays in examples of utterances which are epilogues to the information (examples from 1 to 3 ). The source is mentioned in postposition to the information.

(1) The other big news today was that Russians bought a black lives matter ad and directed it to people living in Ferguson and it was a real threatening 18.50; (2) It knows when you're sleeping 26.16; (3) There was in reference to the study that men and women are discriminated equally after the age of 40 in tech careers 42.27 .

In English there are a lot of examples with anonymous source as well (example 1 and 2) or with indication of a written document as a source of information (example 3).

(1) Amazon is clearly not happy about this 4.06; (2) Amazon is probably using Youtube API / I'm guessing 4.45; (3) Instant video app to Android finally doesn't support chromecast 5.58; (4) Today Apple posted a white paper on how Face ID works / and how it keeps your face secure 6.21 ; (4) Google is really good with kids 10.01 ; (5) Now the company seems to have a solution 12.10; (6) They're repurposing it to their servers 12.24; (7) They're improving things in many ways / to try to figure out can you be social and also private 14.11 ; (8) Their prior method to this involves creating cryptographing hash of the contacts 14.30; (9) Both sides are upset about ideas / and content they don't like 16.41; (10) I'm sure the folks at Facebook / Google are worried about that 19.53

The attribution of personal reactions to companies while reporting facts on their activity can be classified as the informing based on data which are received with conclusions, i.e. interference (examples from 1 to 10). This type of informing does not refer to the reporting category, however it constitutes the periphery of the indirect evidentiality category.

(1) Amazon announced ten new devices all under $\$ 150$ 0:12; (3) Verge contacted Amazon who said Google made the change based on no technical reason 2.32; (4) Google rebutted by saying Amazon's implementation of Youtube / on the Show violates their Terms and Conditions 2.40; (5) Stacey Higginbotam on this weekend reported / that Google has an interesting point and I hadn't considered what is the fact that fire tablets don't have Google services on them 5.05 ; (6) Apple says / that the probability / that a random person in population can look at your IPhone 10 and unlock it using Face ID is approximately 1 in 1 million. 7.02; (7) They say / it doesn't work for kids under 13 9.28; (8) But it's relatively easy / they say / to run all possible phonenumbers through the hash process 14.36; (9) Recode reports that Facebook, Google and Twitter have 
been asked to testify before the Senate Intelligence committee 15.13; (10) The social media had been heating up all year / but has reach a fever pitch following Facebook's disclosure that Russians bought hundred thousand dollar ads on the website during the 2016 elections 15.21; (11) Sources told that executives of Twitter / Google and Facebook will be asked tough questions about how the Kremlin used their platform to spread disinformation 15.32; (12) According to the report of the Daily Beast today / in addition to buying online ads Russians posed the group / called the United Muslims of America 15.46; (13) Today the President weighed on a tweet / saying that Facebook was always Anti-Trump 15.58; (14) He also said in this response / that Trump says the Facebook is against him 16.36; (15) Amazon announced oodles / a new product 20.31; (16) The echo shows that one of the screen is constant 27.04; (17) Amazon says this is the first in their Alexa gadgets lineup 37.54.

The reporting category is presented with a wide range of examples (from 1 to 17), in which the source of information is clearly determined. A verb to say is used most often within function of reporting.

\section{Discussion}

We presented here the results of analysis with using of a continuous sampling method for examples from a speech flow of television programs. However, there are different ways to analyze the pragmatic potential.

The first variant includes the analysis of speech facts in the video record or in the speech itself. It is necessary to consider the speech fact in 3 steps: 1) language representation - which syntactic and lexical means with their morphological characteristics present an evidentiality marker - surface level; 2) semantics which source of information is represented, which type of information is presented; 3) pragmatic potential description of communication conditions and the illocutive effect which was expected to be reached by speaker, if possible - with perlocutive effect taken in mind [6]. Let us consider the analysis of an example from the multimedia corpus of the National corpus of Russian language [7]:

Наташа: Лёнь / ты́ вино́ лю́бишь? / Lyonya / do you like wine?

Ленька: Не́m. Я́ пи́во люблю́. / No, I like beer.

Наташа: Пи́во / э́то ещё ничего́. Пи́во да́же поле́ зно. Осо́бенно / говорят / с молоко́м. / Beer / that's nothing. Beer is even wholesome. Especially, / they say, / with milk.

Ленька: Попробуем! / Let's try! (Л. Кулиджанов. Когда деревья были большими, к/ф / L. Kulidzhanov. When trees were big, movie).

Representation. Two separate sentences represent a link to the soirce of information - говорят / they say and the information itself Пиво да́же поле́зно. Особбенно / с молоком. / Веег / that's nothing. Beer is even wholesome. Especially, with milk. The complete sentence with subject пиво / beer and predicate полезно / wholesome, which is expressed with the short form of adjective, represents the information. The second incomplete sentence contains additional, clarifying information - indirect object (пиво) $c$ молоком / (beer) with milk and intensifier of predicate особенно (полезно)/ especially (wholesome). Detached opening sentence represents a link to the source говорят / they say in the second incomplete sentence. The source of information is expressed by impersonal sentence and additional information. Semantics. The source of information is anonymous. It can be classified as something widely thought in society because the mentioned information that 'beer is wholesome with milk' is not specific but it represents an undated fact, an affirmation without time localization. This sentence is presented as a generally accepted fact, which is known by a group of people. Pragmatic potential. In this situation speakers discuss drinks for a celebration. A girl finds out tastes of her friend who says that he likes beer and not wine. The girl agrees with his choice noticing that beer in comparison with wine is less harmful: Пиво /э́то ещё ничего' / Beer / that's nothing. То confirm in her opinion about safety and even effectiveness of beer, the girl gives a common fact with link to a widely thought opinion in society. This link serves to support her opinion and authority. In this case we see an 'increasing' in authority with using another's information.

The second variant includes the analysis of speech facts in the context. This kind of analysis of pragmatic potential of evidentiality markers дескать / allegedly, мол / alleging that, де / they say in Russian language is presented in the MPhil thesis of I. Shestukhina. This analysis is based on the supposal that the text organization of a composition includes colloquial elements. I. Shestukhina introduces the notion of 'evidential contextual and spoken unit' as a structure unit of a narrative text. A text fragment is taken from a paragraph and includes evidential markers, contextual (description of situation) and spoken (representation) components. In the sphere of narratology 3 categories are divided: 'action', 'point of view' and 'utterance' which are associated with the evidentiality. There is an interesting conclusion that 'a narrative text has potential evidential resources because it already has a function of retelling'. I. Shestukhina came to a conclusion that particles дескать / allegedly, мол / alleging that, де / they say combine indicative and emotional and estimation functions and they form negative, neutral or positive attitude of the reader to the information. We cite a variant of analysis according to the model of I. Shestukhina.

Василек, иди обедать, - звала супруга. [И даже домработнича, правда, конфузясь, называла его за глаза Васильком, хихикая при этом и покачивая головой, - дескать, выдумали, черти, бесятся от излишнего жиру]

Vasilyok, let's have a dinner, - called his wife. [And even the housemaid though being confused called him behind his back Vasilyok, giggling and shaking her head - she said, they did think out, these devils, too much of a good thing]. (M. Zoschenko. Returned youth. (M. Зощенко. Возвращенная молодость) [8, p. 94]. 
Formal mean of expression: relative and indicative particle дескать / she said. Speech unit: "дескать, выдумали, черти, бесятся от излишнего жиру” / 'she said, they did think out, these devils, too much of a good thing'. Speech context: the speech unit is associated with a gesture (an element of somatic language) and represents its verbal reflection, explains it. The speech context is the situation of visual action event.

Subjective organization: speaker - the housemaid, an observer of a gesture, non-verbalized speech unit; undetermined addressee - Vasilyok's wife, Vasilyok himself, other possible witnesses of the situation. The situation is not strongly connected with a concrete moment of speech and it denotes a repeated action of the subject within an uncertain period of time (называла / called - a verb of imperfective aspect, хихикая, покачивая / giggling, shaking - verbal adverbs of imperfective aspect); third subject is hidden behind the division of inner and outer nature of the speaker, speaking gesture - the outer representation of a subject, its meaning - the inner speech of a character, his or her mental ant psychological nature (author-causator) which is presented to the reader.

Speech patterns: colloquial, rusticated units дескать / she said, черти / these devils, бесятся / too тисh of a good thing, forms of government - от излишнего жиру I too much of a good thing - form the corresponding image of the speaking (the thinking) subject. Function: connecting element - the particle дескать / she said conjoin the speech unit and the speech context. The unit under consideration is included into the text as a commentary to the described situation: "the wife calls her husband to eat", and in comparison, with text it exists in another spaciotemporal platitude.

\section{Conclusion}

In summary, the analysis of examples in both of languages demonstrated that the common pragmatic function of informing a priori is specific for mass-media news programs. In this case examples of informing on the latest news in science were analyzed. The essence of the information representation supposes the retelling of other's information - the realization of the reporting category. In the IT sphere journalists themselves rarely become the participants of reported news because they are not connected with this kind of activity. The gradation of particularity degree is as follows: 1) implication of source presence while reporting a scientific fact with reference to its subject; 2) anonymous informing; 3) informing as a result of activity; 4) indication of a source of information. Cluster of facts without source indication is represented separately. In this case this refers to: 1)implication of source of information with indication of fact's participant; 2) description of programs' and devices' functions which suggests the presence of these companies which produced it and explained the functions [9,2016].

In English anonymous sources are represented less within the informing process and the category of inference is used. Attribution of personal reactions to companies while reporting about their activity needs to be considered as informing based on data which were received with conclusion or inference. This informing method is not classified as reporting category; however it forms the periphery of indirect evidentiality category.

In Russian, information is often given as the fruits of labor, the achievement, the activity result of particular subjects who are suggested to be sources of information $[10,2002]$.

\section{References}

1. A.Y. Aikhenvald, Studies in evidentiality. Typological studies in language 54 (John Benjamins Publishing Company, Amsterdam, 2003)

2. A. Aikhenvald, Evidentiality (Oxford University Press, Oxford, 2004)

3. «Technological Wonder: What You Need to Know about Blood, Pluses of Japanese Bath Wisp and Force Cup with Hydroshock ». URL: https://tvshow.com.ua/video/310747/ (date of access: 29.03.18)

4. Tech News Today 1862: Screen Infiltration (27.09.2017). URL: https://www.youtube.com/watch? $\mathrm{v}=\operatorname{asIgKmTP} 1 \mathrm{Gg}$ (date of access: 01.04.18)

5. Ch. Davis, Ch. Potts, M. Speas, The Pragmatic Values of Evidential Sentences (CLC Publications, NY, 2017)

6. G.F. Lutfullina, Questions of Theoretical and Applied Linguistic 4(1), 40-48. (2018)

7. Russian National Corpus. URL: http://www.ruscorpora.ru/en/index.html (date of access: 03.04.18)

8. I. Yu. Shestukhina, The category of evidentiality in Russian narrative text: communicative and pragmatic aspect. MPhil thesis. (Altai State Pedagogical Academy, Barnaul, 2009)

9. G.F. Lutfullina, Man In India 96(3), 771-777 (2016)

10. A.V. Bondarko. Theory of meaning in the system of functional grammar: as exemplified in Russian (Yazyki Slavyanskoy Kultury, Moscow, 2002 